\title{
Determinants of Accounting Information Technology Adoption in Syaria Micro Financial Institutions
}

\author{
Ngadiman ${ }^{1}$, Dhidi Pambudi ${ }^{1}$, Dewi Kusuma Wardani ${ }^{1} \&$ Muhammad Sabandi ${ }^{1}$ \\ ${ }^{1}$ Teacher Training and Education Faculty, Sebelas Maret University, Surakarta, Indonesia \\ Correspondence: Ngadiman, Teacher Training and Education Faculty, Sebelas Maret University, Surakarta, \\ Indonesia. E-mail: ngadiman_uns@yahoo.com
}

$\begin{array}{lc}\text { Received: March 27, } 2014 & \text { Accepted: May 13, } 2014 \quad \text { Online Published: June 24, } 2014 \\ \text { doi:10.5539/ass.v10n14p93 } & \text { URL: http://dx.doi.org/10.5539/ass.v10n14p93 }\end{array}$

\begin{abstract}
The goal of this study is to develop an accounting information system (AIS) that will positively influence the ease of use and usefulness perception to prepare financial statements according to the Sharia (Islamic law) financial system. It also identifies risks hampering the Baitul Maal wa Tamwil (BMT) in adopting AIS. The system used the technology acceptance model as a guideline. The sample consisted of 68 BMTs from the Indonesian regencies of Klaten, Boyolali, and Sleman. Data were collected with a questionnaire that used a 1-4 score Likert scale. Data were analyzed through partial least squares (PLS) that cover: outer model evaluation in the form of convergent validity, discriminant validity, and composite reliability testing. The test of the structural model was performed with R2. Hypothesis testing viewed the magnitude of the structural path coefficient. Intention was directly influenced by attitude, perceived usefulness, and perceived ease of use. The system quality, relevance, and compatibility were important determinants in the perception of usefulness and ease of use, whereas interface characteristics in the form of exploring power, screen design, and terminology were makers of ease of use. Performance risk, finance risk, and security risk were hampering factors for BMT in adopting the AIS. On the other hand, time risk and social risk were deemed unimportant by BMT.
\end{abstract}

Keywords: accounting information system, technology acceptance model, Baitul Maal wa Tamwil

\section{Introduction}

Baitul Maal wa Tamwil (BMT) is a micro financial institution that operates under the principle of profit sharing to help micro enterprises expand their business. BMT operates under the 'salam' (safe) economy principle, which includes the values of justice, peace, and prosperity (Surahman, Suhrowardi, \& Ersa, 2009). The objective of BMTs is to improve the prosperity of its members and their surrounding community. To achieve the objective, BMTs develop productive business activities and encourage more investment, especially for small and medium enterprises (SMEs). To support this agenda, BMT needs to utilize information technology.

Lee (2008) reported that the application of on-line banking can reduce operational cost and time and monitor all transactions continuously. In Uganda, Ssewanyana (2009) also reported that the use of information computer technology (ICT) has improved efficiency, services, and performance of micro financial institutions. Pierre, Khalil, Marwan, Nivine, and Tarek (2013) reported that the use of an accounting information system (AIS) has saved time and improved the accuracy and security of the transactions. Zakaria, Rahman, and Elsayed (2011) stated that the use of electronic accounting among public institutions in Malaysia has improved budgeting, accounting, reporting, and auditing performance as well as the control of tasks in public institutions.

Not many BMTs, however, have adopted information technology. The problems encountered are the low level of human resources' technology adoption. Human resources are very important for the success of an organization. Ulrich (1988), stated that the key of success for a change lies on human resources, namely as the initiator and continuous agent of a change, the maker of process and culture jointly improving ability of the organizational change. This study then seeks to answer two questions: What should be done to encourage BMTs to adopt an AIS? What determinants should BMTs consider when adopting an AIS?

\section{Literature Review}

\subsection{Development of an AIS}

According to Hall (2006), an AIS is developed to support the stewardship function in providing information 
about resources management to achieve the goal. Moorthy, Voon, Samsuri, Gopalan, \& Yew (2012) emphasized that an electronic AIS is important because it can provide information required for decision making. Electronic AISs also improve the effectiveness and efficiency of daily activities of an organization (Khalily, 2004; Kholis, 2007). The use of an electronic AIS will reduce operational costs as it enhances planning, business management, and transactional activities (Khan, 2005; Kholis, 2007; Slater \& Tacchi, 2004). The use of an information system in BMTs also helps publicize BMT's products to the potential customers (Karjaluato, Koivumaki, \& Salo, 2003; Sadeq, 2007).

The AIS can generate not only financial accounting reports but also the management accounting reports and other non-financial reports (Moorthy et al., 2012). In addition, according to Tesic (2012) and Hall (2006), the AISs currently are becoming more sophisticated because they can integrate organizations electronically. AISs can also function as input providers or triggers to develop other functional management information systems (Konchitchki \& O'Leary, 2012).

\subsection{Information Technology and the Performance of Micro Financial Institutions}

The use of information system at micro financial institutions improves their performance through competitive excellence, cost reduction, capacity growth, and efficiency (Bhatt, Nitin, \& Tang, 2002; Khan, 2005; Kholis, 2007). Ritchie and Brindley (2005) stated that the right use of technology can also improve the performance of micro financial institutions. There are five key indicators that determine whether the information technology used at a micro financial institution is effective in improving its performance. The first indicator is quality, that is, whether the organization can achieve the objectives with the help of technology. The second indicator is punctuality, measuring the time required to perform an activity. The third indicator is cost effectiveness. The use of technology should be able to create the cost effectiveness. The fourth indicator is whether supervision is still needed when the institution has adopted information technology. The last indicator is interpersonal impact, which observes whether the employees of micro financial institutions are able to maintain their self-prestige, good reputation, and cooperation with colleagues and subordinates.

\subsection{Technology Acceptance Model (TAM)}

This study follows the technology acceptance model (TAM) framework with the addition of external variable antecedents identified from previous studies. The model is also modified with other existing models, such as theory of reasoned action (TRA) and theory of planned behavior (TPB).

TRA and TPB explain about the relation between attitude, intention, and behavior. According to TPB, human behavior is directly motivated by an intention to perform the behavior. Intention is determined by the individual attitude towards the behavior, subjective norms, and behavioral control. Intention, according to Ajzen (1991), is an indication of how hard a person is willing to try and how much effort a person will make to perform an action (applying the information technology). Attitude towards behavior also stimulates a person's intention. As stated by Ajzen (1991), attitude refers to the evaluation of a behavior. Some studies have indicated that attitude affects the intention to perform a behavior, although with less significance (Figure 1).

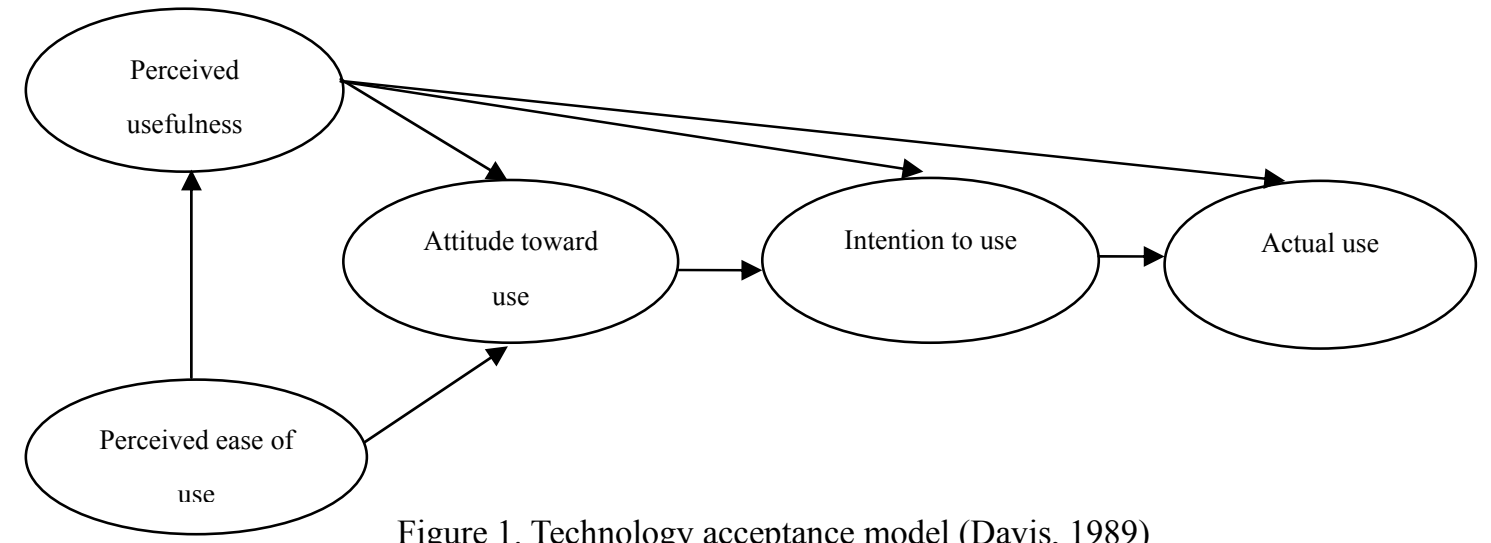

Figure 1. Technology acceptance model (Davis, 1989)

TAM was developed by Davis (1989) to predict the use of information technology and the benefits for the users. TAM is the extension of TRA and TPB that is based on the understanding that the intention to use an information system is determined by two main determinants: usefulness and ease of use perception (Davis, 1993; Venkatesh \& Davis, 2000; Venkatesh, Moris, \& Davis, 2003). 
The first determinant is perception of usefulness. Davis (1989) defined the perception of usefulness as the extent to which a person believes that using a technology will enhance her or his performance. The second determinant is the ease of use perception. Davis $(1989,1993)$ defined this perception as the extent to which a person believes that using technology will be free from effort. These two factors affect the decision-making process. If a person believes that an information system is useful and easy to use, he will use it. On the contrary, if a person believes that an information system is not useful or not easy to use, he will not use it.

Referring to the framework of TAM, TRA, and TPB, the hypotheses of this study are formulated as follows:

H1: Attitude has a positive influence to the intent to use the AIS.

H2: Usefulness perception has a positive influence on the intention to use the AIS.

H3: Usefulness perception has a positive influence on the attitude in using the AIS.

H4: Ease of use perception has a positive influence on the attitude in using the AIS.

H5: Ease of use perception has a positive influence on the usefulness perception in using the AIS.

\subsection{Perception Determinants on the Usefulness and Ease of Use of the Information System}

\subsubsection{System Quality}

The success of an information technology depends on the quality of the system, because quality indicates the system operational efficiency. Kim, Lee, and Law (2008) explained that a system that gives fast response, reacts quickly, enhances information exchange, and is flexible in the changes correlates with the ease of use perception and benefits the staff. Jeong (2011) also indicated that quality of the system affects the perception of usefulness and ease of use in using e-library. Ahn, Ryu, and Han (2007) reported that a good quality system has a significant impact on the perceived ease of use and usefulness of the users of online retailing. A good system will give the ease in looking for information and will be considered useful (Figure 2). Therefore, two more hypotheses are then formulated as follows:

H6a: Quality of a system has a positive influence on the usefulness perception in using the AIS.

H6b: Quality of a system has a positive influence to the ease of use perception in using the AIS.

\subsubsection{Relevance}

Relevance refers to how far a system is related to the tasks done as required in the task analysis. Thong, Hong, and Tam (2002) reported that the usefulness of technology will be obtained when someone applies a relevant tool to one's activity. Hong, Thong, Wong, and Tam (2002) corroborated that relevance has a direct impact on the perception of the ease of use and usefulness of an e-library system. Jeong (2011) also indicated that relevance has a positive connection with the perception of usefulness, but it has no significant influence on the perception of ease of using the e-library (Figure 2). Based on this study, the hypotheses can be formulated as follows:

H7a: Relevance has a positive influence on the perception of usefulness in using the AIS.

H7b: Relevance has a positive influence on the perception of ease of use in using the AIS.

\subsubsection{Compatibility}

Compatibility is also found to influence the use of information systems. Compatibility is the degree to which an innovation meets the values, needs, and the past experiences of the potential adopters. An individual will tend to use a system if it fulfills job needs. A study conducted by Crespo and Rodrigues (2008) showed that the compatibility has positive and significant connection with the usefulness perception in using e-commerce. Hu, Clark, and Ma (2003) also reported that compatibility has the impact to the perceived ease of use in adopting the technology (Figure 2). Under the basis of the above description, the hypotheses can be formulated as follows:

H8a: Compatibility has a positive influence on the usefulness perception in using the AIS.

H8b: Compatibility has a positive influence on the ease of use perception in using the AIS.

\subsubsection{Screen Design}

Hong et al. (2002) found that the screen design has the influence on the perception in ease of using a digital library. Screen design is the way information is presented at the screen. Screen design is related to the content arrangement in the matters of layout, color scheme, paragraph format, icon, button, font size, and line spacing. Thong et al. (2002) reported that a system with good screen design will make the digital library easy to use for users. Jeong (2011) also reported that the screen layout that is clear and consistent, and its font, symbols, and buttons are easy to read, will positively influence the perception in the ease of using the digital library. Further, 
good screen design will positively influence the system's perceived usefulness (Figure 2). Based on the above description, the hypotheses can be formulated as follows:

H9a: The screen design has a positive influence on the usefulness perception in using the AIS.

H9b: The screen design has a positive influence on the ease of use perception in using the AIS.

\subsubsection{Exploring Power/Navigation}

Navigation refers to the way to find relevant information. Jeong (2011) stated that a website system that offers users access to interesting information in the website and access to other websites will get positive perceptions from the users, thus influencing the system's perceived usefulness. Thong et al. (2002) also stated that a system completed with a navigation instrument will facilitate looking for information for users (Figure 2). Based on the above description, the hypotheses can be formulated as follows:

H10a: The exploring power has a positive influence on the usefulness perception in using the AIS.

H10b: The exploring power has a positive influence to the ease of use perception in using the AIS.

\subsubsection{Terminology}

Terminology clarity in technology has a significant influence towards the intention and decision to use information technology. Hong et al. (2002), Jeong (2011), and Thong et al. (2002) indicated that terminology clarity has a positive influence on the ease of use perception when using a digital library. Terminology concerns with words, sentences, and abbreviations used in a system. A system with simple technical terms will facilitate the users in looking for information. On the contrary, complicated terms that are difficult to understand will create a negative perception about the system's usefulness (Figure 2). Based on the above description, the hypotheses can be formulated as follows:

H11a: Terminology has a positive influence on usefulness perception in using the AIS.

H11b: Terminology has a positive influence on ease of use perception in using the AIS.

\subsection{Risk Perception towards Behavioral Attitude in Using AIS}

The study conducted by Lee (2009) at an online trading company reported that risk is considered a more influential factor than the perceived usefulness in decision making for online trading by investors. The concern of consumers upon deception and not getting any compensation in case of financial loss causes the low attitude and intention to adopt online banking. Lee (2008) also showed that the performance, security, finance, time, and social risks correlate with the low attitude and intention of adopting the online banking. The concern upon system leak, financial loss due to the wrong transaction or the misuse of bank account, fraud, hacker, and long time required for learning to use the online banking hampers the customers' intention to use the online banking. Risk related to the social judgment in form of disagreement between friends, family, or work group also influences the customers' subjective norm in adopting online banking. Those five risks will certainly influence the attitude of the BMT management to adopt the AIS (Figure 2). Based on the description above, the hypotheses are formulated as follows:

H12: Performance risk has a negative influence on the attitude in using the AIS.

H13: Financial Risk has a negative influence on the attitude in using the AIS.

H14: Security Risk has negative influence on the attitude in using the AIS.

H15: Time Risk has a negative influence on the attitude in using the AIS.

H16: Social Risk has a negative influence on the attitude in using the AIS. 


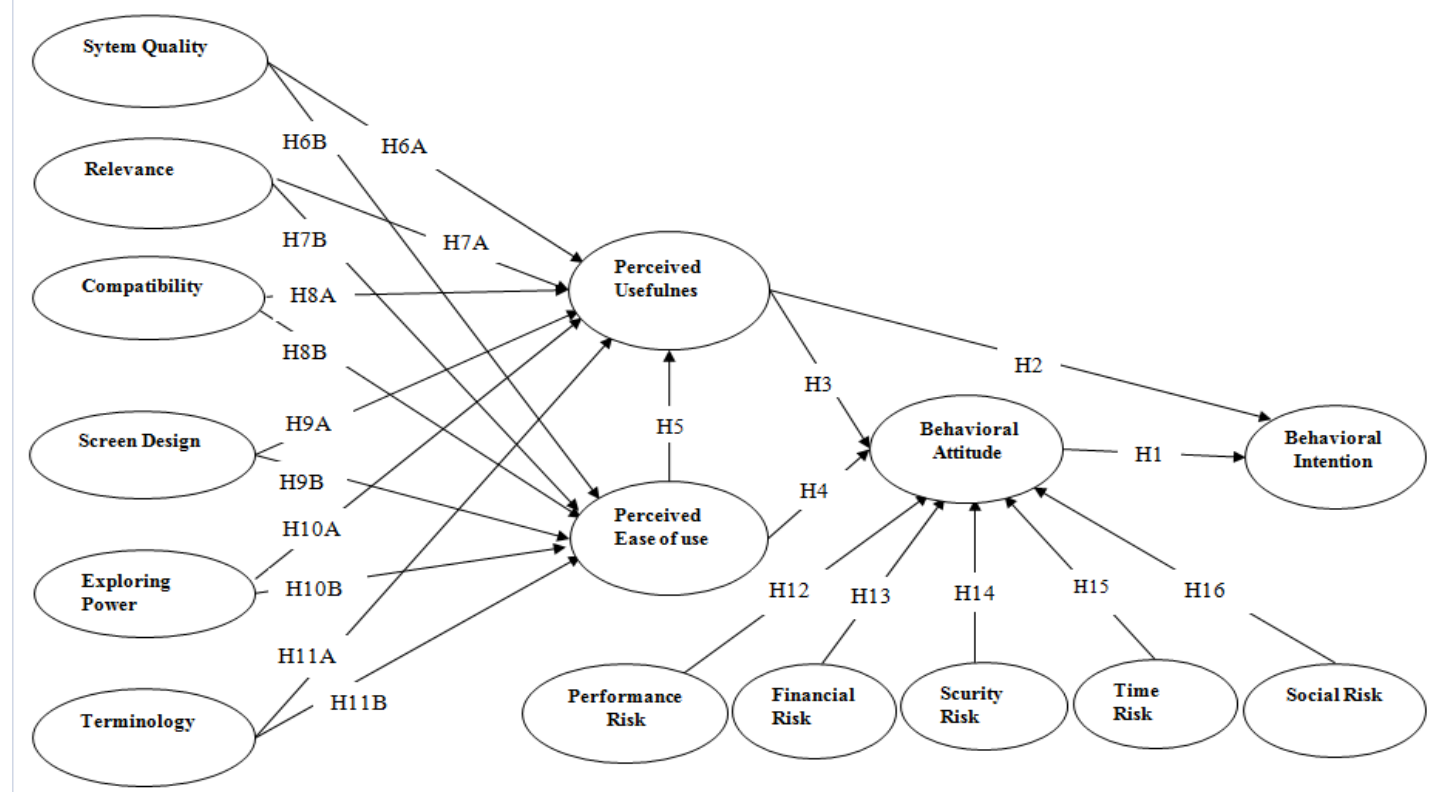

Figure 2. Research model

\section{Research Methodology}

\subsection{Population and Sample}

The populations in this study were all BMTs in the Indonesian regencies of: Klaten, Boyolali, and Sleman. However, the exact total population was difficult to determine due to the lack of available information. Therefore, the samples in this study were the BMTs that are tracked down and were willing to respond the questionnaire. Sixty eight BMTs were included in the sample, 26 from Klaten, 24 from Boyolali, and 18 from Sleman. One person from each BMT, manager or staff, responded the questionnaire.

\subsection{Development of Questionnaire}

The questionnaire in this study had two parts. The first part included information concerning the respondents: sex, age, title, education, and experience using the internet (Table 1). The second part covered variables and items used to measure each variable. Items for the TAM constructs were adopted from Davis (1989). The constructs of exploration/navigation, screen design, terminology, relevance, and system quality were adopted from Thong et al. (2002), Hong et al. (2002), and Jeong (2011). On the other side, risk perception was adopted from Lee (2008). The questionnaire items were first deliberated with the experts through focus group discussion with the purpose of adjusting the language and examining whether the items can represent the concept to be measured. The questionnaire used a 1-4 score Likert scale. Measurement scales used in this study were: strongly disagree, disagree, agree, and strongly agree.

Table 1. Description of respondents

\begin{tabular}{lll}
\hline Subject & Description & Percentage \\
\hline Sex & Male & $75 \%$ \\
Age & Female & $25 \%$ \\
& $<20$ years & $0 \%$ \\
& $21-30$ years & $10.68 \%$ \\
\multirow{2}{*}{ Education } & $31-40$ years & $42,69 \%$ \\
& $>41$ years & $39.81 \%$ \\
& Not stated & $6.82 \%$ \\
Position & Diploma-3 & $44.75 \%$ \\
& Stratum-1 Undergraduate & $58.25 \%$ \\
& Manager & $86.41 \%$ \\
\hline
\end{tabular}




\begin{tabular}{lll}
\hline Subject & Description & Percentage \\
\hline Experience in & $<1$ year & $0 \%$ \\
using computer & $1-2$ years & $0 \%$ \\
& $3-4$ years & $0 \%$ \\
& $>4$ years & $100 \%$ \\
\hline
\end{tabular}

\subsection{Data Analysis}

The partial least square (PLS) structural equation model (SEM) was applied to evaluate the relation among constructs. The PLS-SEM was used because the samples in this research were questionnaires of only 68 respondents, but there were many constructs to develop. As stated by Hair, Ringle, and Sarstedt (2011), and Henseler, Ringle, and Stankovic (2009), PLS offers a better estimation on the small amount of samples, which cannot be handled with other tools (e.g., AMOS).

As the other SEM analytical tools, PLS-SEM involves a two-step approach. The measurement model was used to see the validity and reliability of measurement items, and then the structural model was used to test the relationship between independent latent variables and the dependent variable. Evaluation of internal conditions of a construct can be carried out through the value of composite reliability and Cronbach's alpha with values above 0.70 . The validity test on the reflexive model can be evaluated through the convergent and discriminant validities. Evaluation on convergent validity can be observed through the average variant extraction (AVE). Hair et al. (2011) and Henseler et al. (2009) stated that an AVE value above 0.50 indicates there is sufficient convergent validity, which means that the latent variable describes more than a half of its indicator variants.

Meanwhile, testing the structural model (inner model) was done by viewing R2. Hypothesis testing was carried out by seeing the magnitude of its structural path coefficient and stability of estimation evaluated by using the t-statistic test obtained through the bootstrapping procedure.

\section{Results}

\subsection{Evaluation on Measurement Model}

The measurement model was evaluated by using the reflective indicator through the internal reliability of a construct that can be observed through the value of composite reliability and Cronbach's alpha. Following the statements of Hair et al. (2011) and Henseler et al. (2009), Cronbach's alpha assumes that all indicators are equally reliable, so that they are more suitable for the PLS-SEM, which prioritizes the indicators according to their reliability during the model estimation. A composite reliability value above $0.70-0.90$ for the study under the confirmatory nature is deemed to have been satisfied. Further, the reliability of each indicator needs to be calculated. Hair et al. (2011) and Henseler et al. (2009) stated that the load burden of each indicator must be higher than 0.70 . Indicators with the burden between 0.40 and 0.70 can be accepted under a consideration that if an indicator is eliminated, it will increase the composite reliability above the suggested threshold value. Another consideration on decision to eliminate an indicator is how far such elimination influences the validity. Table 2 shows that the value of loading factor on each indicator is more than 0.70 . Thus, such indicators have a good reliability. The Composite Reliability and Cronbach's Alpha values were also higher than 0.70 and it explains if the reliability test has been fulfilled.

Further, the validity of the latent constructs indicators at the reflexive model can be evaluated through the convergent and discriminant validities. Evaluation on convergent validity can be observed through the Average Variant Extraction (AVE). Hair et al. (2011) and Henseler et al. (2009) stated that the AVE value above 0.50 indicates sufficient level of the convergent validity, which means that the latent variable describes more than a half of its indicator variants. In this research, all constructs have the value of AVE $>0.50$ (Table 2). Thus, the convergent validity test has been met.

Table 2. Convergent validity and construct reliability

\begin{tabular}{llllll}
\hline Construct & Item & Loading Factors & AVE & Composite Reliability & Cronbach's Alpha \\
\hline \multirow{3}{*}{ Intention } & NIAT1 & 0.877 & 0.830 & 0.936 & 0.897 \\
& NIAT2 & 0.940 & & & \\
\multirow{2}{*}{ Attitude } & NIAT3 & 0.913 & & & 0.932 \\
& SKP1 & 0.940 & 0.880 & 0.957 & \\
\hline
\end{tabular}




\begin{tabular}{|c|c|c|c|c|c|}
\hline Construct & Item & Loading Factors & AVE & Composite Reliability & Cronbach's Alpha \\
\hline \multirow{5}{*}{ Usefulness Perception } & SKP3 & 0.924 & & & \\
\hline & PM1 & 0.825 & 0.657 & 0.885 & 0.826 \\
\hline & PM2 & 0.807 & & & \\
\hline & PM3 & 0.804 & & & \\
\hline & PM4 & 0.807 & & & \\
\hline \multirow{4}{*}{ Ease of Use Perception } & PKM1 & 0.832 & 0.667 & 0.889 & 0.835 \\
\hline & PKM2 & 0.820 & & & \\
\hline & PKM3 & 0.819 & & & \\
\hline & PKM4 & 0.795 & & & \\
\hline \multirow{3}{*}{ System Quality } & KS1 & 0.839 & 0.754 & 0.902 & 0.837 \\
\hline & KS2 & 0.895 & & & \\
\hline & KS3 & 0.871 & & & \\
\hline \multirow{3}{*}{ Relevance } & REL1 & 0.791 & 0.631 & 0.836 & 0.706 \\
\hline & REL2 & 0.849 & & & \\
\hline & REL3 & 0.739 & & & \\
\hline \multirow{3}{*}{ Compatibility } & KOM1 & 0.796 & 0.637 & 0.840 & 0.715 \\
\hline & KOM2 & 0.733 & & & \\
\hline & KOM3 & 0.861 & & & \\
\hline \multirow{3}{*}{ Exploring Power } & DJ1 & 0.855 & 0.688 & 0.868 & 0.772 \\
\hline & DJ2 & 0.772 & & & \\
\hline & DJ3 & 0.859 & & & \\
\hline \multirow{2}{*}{ Screen Design } & DL1 & 0.912 & 0.767 & 0.868 & 0.702 \\
\hline & DL2 & 0.838 & & & \\
\hline \multirow{3}{*}{ Terminology } & TRM1 & 0.881 & 0.719 & 0.884 & 0.803 \\
\hline & TRM2 & 0.782 & & & \\
\hline & TRM3 & 0.876 & & & \\
\hline \multirow{2}{*}{ Security Risk } & RKEA1 & 0.867 & 0.780 & 0.876 & 0.719 \\
\hline & RKEA2 & 0.900 & & & \\
\hline \multirow{2}{*}{ Financial Risk } & RKEU1 & 0.920 & 0.810 & 0.895 & 0.767 \\
\hline & RKEU2 & 0.880 & & & \\
\hline \multirow{2}{*}{ Performance Risk } & RK1 & 0.919 & 0.848 & 0.918 & 0.821 \\
\hline & RK2 & 0.923 & & & \\
\hline \multirow{2}{*}{ Social Risk } & RS1 & 0.876 & 0.790 & 0.883 & 0.735 \\
\hline & $\mathrm{RS} 2$ & 0.902 & & & \\
\hline \multirow{2}{*}{ Time Risk } & RW1 & 0.951 & 0.753 & 0.858 & 0.703 \\
\hline & RW2 & 0.776 & & & \\
\hline
\end{tabular}

The evaluation of discriminant validity can be carried out in two ways. Hair et al. (2011) and Henseler et al. (2009) stated that testing the discriminant validity can be conducted by comparing the root of AVE for each construct with the correlation between one construct with another construct in a model. The AVE root of each latent construct must be higher than the latent construct correlation of the other respective latent construct. The second criteria of discriminant validity are that the indicator loading value and latent construct must be higher than the loading value of all the remaining constructs (i.e., cross loading).

From the comparison between the AVE root value and the coefficient of the latent variable correlation (Table 3), it can be concluded that the AVE root of the exploring power construct is 0.830 , which is higher than the correlation between the exploring power construct and the other, and so are the constructs. This indicates that the discriminant validity testing has been fulfilled.

Table 3. Value of latent variable correlations

\begin{tabular}{llllllllllllllll}
\hline $\begin{array}{l}\text { Variable } \\
\mathrm{s}\end{array}$ & 1 & 2 & 3 & 4 & 5 & 6 & 7 & 8 & 9 & 10 & 11 & 12 & 13 & 14 & 15 \\
\hline $\begin{array}{l}\text { Explorin } \\
\text { g Power }\end{array}$ & $\mathbf{0 . 8}$ & $\mathbf{3 0}$ & & & & & & & & & & & & &
\end{tabular}




\begin{tabular}{|c|c|c|c|c|c|c|c|c|c|c|c|c|c|c|c|}
\hline $\begin{array}{l}\text { Variable } \\
\text { s }\end{array}$ & 1 & 2 & 3 & 4 & 5 & 6 & 7 & 8 & 9 & 10 & 11 & 12 & 13 & 14 & 15 \\
\hline $\begin{array}{l}2 . \\
\text { Screen } \\
\text { Design }\end{array}$ & $\begin{array}{l}0.4 \\
51\end{array}$ & $\begin{array}{l}0.8 \\
76\end{array}$ & & & & & & & & & & & & & \\
\hline $\begin{array}{l}3 . \\
\text { Compati } \\
\text { bility }\end{array}$ & $\begin{array}{l}0.4 \\
81\end{array}$ & $\begin{array}{l}0.4 \\
96\end{array}$ & $\begin{array}{l}0.7 \\
98\end{array}$ & & & & & & & & & & & & \\
\hline $\begin{array}{l}4 . \\
\text { System } \\
\text { Quality }\end{array}$ & $\begin{array}{l}0.5 \\
35\end{array}$ & $\begin{array}{l}0.5 \\
72\end{array}$ & $\begin{array}{l}0.6 \\
45\end{array}$ & $\begin{array}{l}0.8 \\
68\end{array}$ & & & & & & & & & & & \\
\hline $\begin{array}{l}5 . \\
\text { Intention }\end{array}$ & $\begin{array}{l}0.5 \\
30\end{array}$ & $\begin{array}{l}0.4 \\
34\end{array}$ & $\begin{array}{l}0.6 \\
01\end{array}$ & $\begin{array}{l}0.6 \\
64\end{array}$ & $\begin{array}{l}0.91 \\
1\end{array}$ & & & & & & & & & & \\
\hline $\begin{array}{l}\text { 6. Ease } \\
\text { Pertcept. }\end{array}$ & $\begin{array}{l}0.6 \\
13\end{array}$ & $\begin{array}{l}0.6 \\
77\end{array}$ & $\begin{array}{l}0.5 \\
35\end{array}$ & $\begin{array}{l}0.6 \\
99\end{array}$ & $\begin{array}{l}0.6 \\
05\end{array}$ & $\begin{array}{l}0.8 \\
17\end{array}$ & & & & & & & & & \\
\hline $\begin{array}{l}7 . \\
\text { Usefulne } \\
\text { ss Perc }\end{array}$ & $\begin{array}{l}0.4 \\
94\end{array}$ & $\begin{array}{l}0.5 \\
40\end{array}$ & $\begin{array}{l}0.7 \\
09\end{array}$ & $\begin{array}{l}0.7 \\
66\end{array}$ & $\begin{array}{l}0.7 \\
17\end{array}$ & $\begin{array}{l}0.7 \\
38\end{array}$ & $\begin{array}{l}0.81 \\
1\end{array}$ & & & & & & & & \\
\hline $\begin{array}{l}8 . \\
\text { Relevan } \\
\text { ce }\end{array}$ & $\begin{array}{l}0.3 \\
45\end{array}$ & $\begin{array}{l}0.3 \\
28\end{array}$ & $\begin{array}{l}0.4 \\
30\end{array}$ & $\begin{array}{l}0.5 \\
17\end{array}$ & $\begin{array}{l}0.3 \\
67\end{array}$ & $\begin{array}{l}0.5 \\
22\end{array}$ & $\begin{array}{l}0.6 \\
09\end{array}$ & $\begin{array}{l}0.7 \\
94\end{array}$ & & & & & & & \\
\hline $\begin{array}{l}9 . \\
\text { Security } \\
\text { Risk }\end{array}$ & $\begin{array}{l}-0.1 \\
63\end{array}$ & $\begin{array}{l}-0.2 \\
71\end{array}$ & $\begin{array}{l}-0.2 \\
56\end{array}$ & $\begin{array}{l}-0.2 \\
74\end{array}$ & $\begin{array}{l}-0.4 \\
38\end{array}$ & $\begin{array}{l}-0.2 \\
90\end{array}$ & $\begin{array}{l}-0.3 \\
17\end{array}$ & $\begin{array}{l}-0.1 \\
32\end{array}$ & $\begin{array}{l}0.8 \\
83\end{array}$ & & & & & & \\
\hline $\begin{array}{l}10 . \\
\text { Financia } \\
1 \text { Risk }\end{array}$ & $\begin{array}{l}-0.2 \\
28\end{array}$ & $\begin{array}{l}-0.1 \\
84\end{array}$ & $\begin{array}{l}-0.2 \\
19\end{array}$ & $\begin{array}{l}-0.3 \\
22\end{array}$ & $\begin{array}{l}-0.3 \\
75\end{array}$ & $\begin{array}{l}-0.3 \\
68\end{array}$ & $\begin{array}{l}-0.3 \\
26\end{array}$ & $\begin{array}{l}-0.2 \\
06\end{array}$ & $\begin{array}{l}-0.2 \\
35\end{array}$ & $\begin{array}{l}0.9 \\
00\end{array}$ & & & & & \\
\hline $\begin{array}{l}11 . \\
\text { Perform } \\
\text { ance R. }\end{array}$ & $\begin{array}{l}-0.2 \\
10\end{array}$ & $\begin{array}{l}-0.2 \\
38\end{array}$ & $\begin{array}{l}-0.2 \\
22\end{array}$ & $\begin{array}{l}-0.3 \\
04\end{array}$ & $\begin{array}{l}-0.5 \\
47\end{array}$ & $\begin{array}{l}-0.4 \\
03\end{array}$ & $\begin{array}{l}-0.4 \\
16\end{array}$ & $\begin{array}{l}-0.2 \\
25\end{array}$ & $\begin{array}{l}-0.2 \\
68\end{array}$ & $\begin{array}{l}-0.3 \\
28\end{array}$ & $\begin{array}{l}0.9 \\
21\end{array}$ & & & & \\
\hline $\begin{array}{l}12 . \\
\text { Social } \\
\text { Risk }\end{array}$ & $\begin{array}{l}-0.0 \\
33\end{array}$ & $\begin{array}{l}-0.0 \\
83\end{array}$ & $\begin{array}{l}0.0 \\
70\end{array}$ & $\begin{array}{l}-0.0 \\
52\end{array}$ & $\begin{array}{l}-0.1 \\
04\end{array}$ & $\begin{array}{l}-0.0 \\
45\end{array}$ & $\begin{array}{l}-0.0 \\
12\end{array}$ & $\begin{array}{l}-0.0 \\
63\end{array}$ & $\begin{array}{l}0.3 \\
48\end{array}$ & $\begin{array}{l}0.3 \\
05\end{array}$ & $\begin{array}{l}0.1 \\
32\end{array}$ & $\begin{array}{l}0.8 \\
89\end{array}$ & & & \\
\hline $\begin{array}{l}\text { 13. Time } \\
\text { Risk }\end{array}$ & $\begin{array}{l}0.0 \\
62\end{array}$ & $\begin{array}{l}0.0 \\
66\end{array}$ & $\begin{array}{l}0.0 \\
80\end{array}$ & $\begin{array}{l}-0.0 \\
92\end{array}$ & $\begin{array}{l}0.0 \\
10\end{array}$ & $\begin{array}{l}0.0 \\
09\end{array}$ & $\begin{array}{l}-0.0 \\
74\end{array}$ & $\begin{array}{l}0.0 \\
76\end{array}$ & $\begin{array}{l}0.11 \\
3\end{array}$ & $\begin{array}{l}0.0 \\
22\end{array}$ & $\begin{array}{l}0.2 \\
01\end{array}$ & $\begin{array}{l}0.1 \\
90\end{array}$ & $\begin{array}{l}0.9 \\
38\end{array}$ & & \\
\hline $\begin{array}{l}14 . \\
\text { Attitude }\end{array}$ & $\begin{array}{l}0.4 \\
55\end{array}$ & $\begin{array}{l}0.4 \\
70\end{array}$ & $\begin{array}{l}0.4 \\
86\end{array}$ & $\begin{array}{l}0.6 \\
55\end{array}$ & $\begin{array}{l}0.7 \\
39\end{array}$ & $\begin{array}{l}0.7 \\
19\end{array}$ & $\begin{array}{l}0.7 \\
00\end{array}$ & $\begin{array}{l}0.5 \\
44\end{array}$ & $\begin{array}{l}-0.5 \\
14\end{array}$ & $\begin{array}{l}-0.5 \\
04\end{array}$ & $\begin{array}{l}-0.5 \\
98\end{array}$ & $\begin{array}{l}-0.2 \\
37\end{array}$ & $\begin{array}{l}-0.1 \\
70\end{array}$ & $\begin{array}{l}0.9 \\
38\end{array}$ & \\
\hline $\begin{array}{l}15 . \\
\text { Tertmino } \\
\text { logy }\end{array}$ & $\begin{array}{l}0.2 \\
97\end{array}$ & $\begin{array}{l}0.4 \\
97\end{array}$ & $\begin{array}{l}0.4 \\
13\end{array}$ & $\begin{array}{l}0.5 \\
14\end{array}$ & $\begin{array}{l}0.5 \\
12\end{array}$ & $\begin{array}{l}0.5 \\
65\end{array}$ & $\begin{array}{l}0.4 \\
66\end{array}$ & $\begin{array}{l}0.3 \\
91\end{array}$ & $\begin{array}{l}-0.1 \\
09\end{array}$ & $\begin{array}{l}-0.2 \\
50\end{array}$ & $\begin{array}{l}-0.1 \\
32\end{array}$ & $\begin{array}{l}-0.0 \\
42\end{array}$ & $\begin{array}{l}0.0 \\
15\end{array}$ & $\begin{array}{l}0.4 \\
44\end{array}$ & $\begin{array}{l}0.8 \\
48\end{array}$ \\
\hline
\end{tabular}

$\mathrm{l}^{*}$ Note: Figures in bold type is the roots of AVE

\subsection{Structural Model Evaluation}

The structural model or inner model was evaluated by looking at the value of R2 for each endogenous latent variable, as prediction power of structural model. Testing the hypotheses in this study was performed by viewing the magnitude of the coefficient of its structural path and stability of estimation evaluated by using t-statistic test obtained through the bootstrapping procedure.

The R2 value of the intention variable at the value of 0.624 means that the intention variable applies the accounting information system influenced by attitude and usefulness perception at the amount of $62.4 \%$. The attitude variable were influenced by usefulness perception, ease of use perception, performance risk, financial risk, time risk, social risk, and security risk at the sum of $75.7 \%$. The usefulness perception and the ease of use perception were influenced by variables of exploring power, screen design, terminology, system quality, relevance, and compatibility respectively at the amount of $75.4 \%$ and $69.1 \%$ (Figure 3 ). 


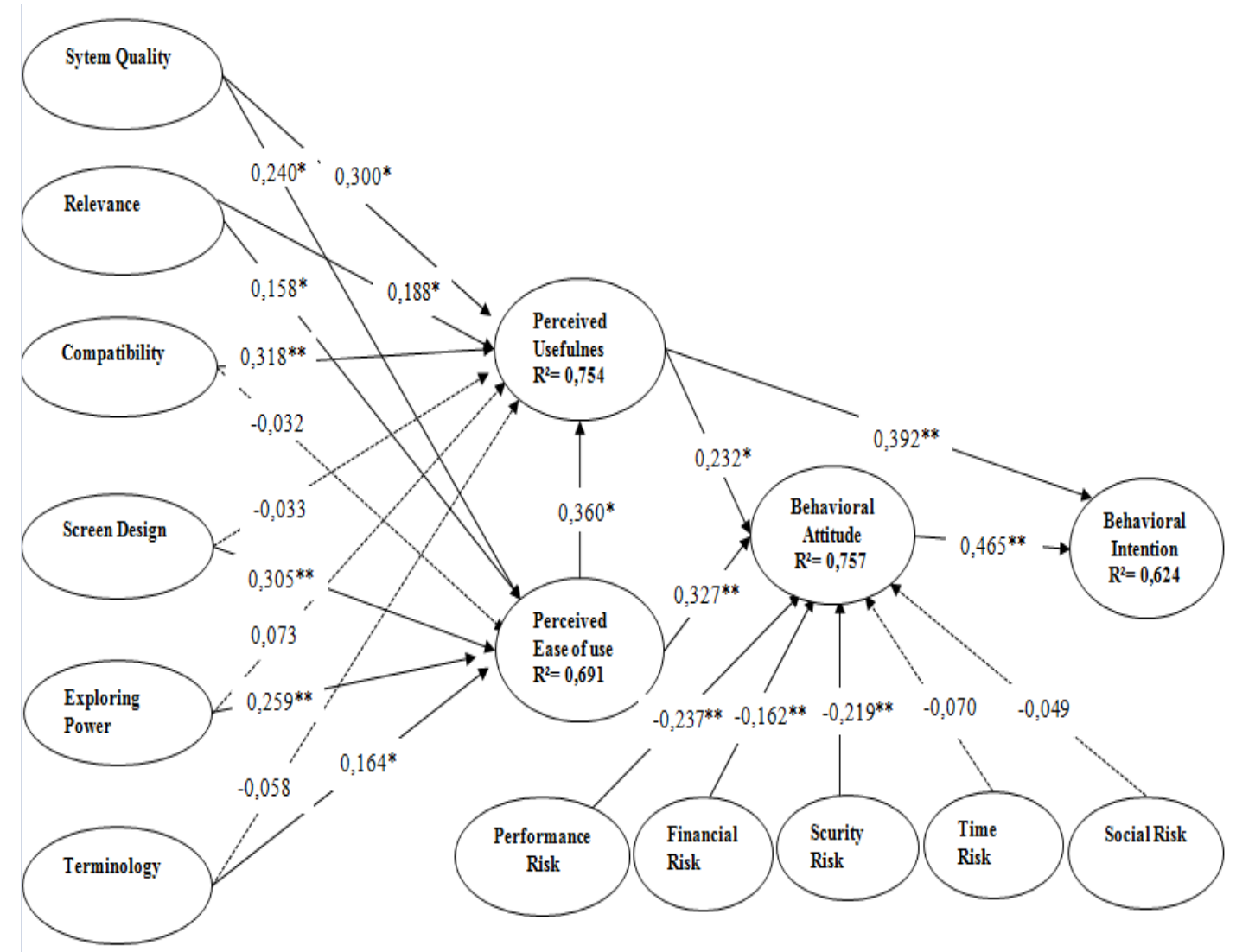

Figure 3. Structural model testing

Note: Path Coefficient:

** Significant at the stage of $1 \%$ (t-statistics $=>2.576)$

* Significant at the stage of $5 \%$ (t-statistics $=>1.960$ )

\subsection{Hypothesis Testing}

Table 4 indicates the values of hypothesis coefficient paths. The test outputs show that all TAM constructs have significant influence, so that $\mathrm{H} 1, \mathrm{H} 2, \mathrm{H} 3, \mathrm{H} 4$, and $\mathrm{H} 5$ are accepted. All parameters of the system that include system quality, relevance, and compatibility gave significant influence to the usefulness perception and ease of use, except compatibility parameter to the ease of use perception. The parameter of the system that contributed the biggest influence to the ease of use perception was compatibility, indicated by $\beta=0.318$, followed by system quality $(\beta=0.300)$, and relevance $(\beta=0.188)$, whereas influence to the usefulness perception for the relevance is at the amount of $\beta=0.158$, system quality $(\beta=240)$, and compatibility $(\beta=-0.032)$. In this way, H6a, H6b, H7a, $\mathrm{H} 7 \mathrm{~b}$, and $\mathrm{H} 8 \mathrm{a}$ are supported, while $\mathrm{H} 8 \mathrm{~b}$ is not supported.

Interface characteristics that include screen design, exploring power, and terminology were found to be influential to the ease of use perception. From the three determinant factors, the screen design has the biggest influence. This is indicated by the value of $\beta=0.305$, followed by exploring power $(\beta=0.259)$, and terminology $(B=0.164)$. Thus, H9b, H10b, and H11b are accepted, while H9a, H10a, and H11a are not supported.

Regarding risks, only performance risk, financial risk, and security risk were found to be influential towards attitude, which is indicated by $\beta=-237 ; \beta=-0.162$; and $\beta=-0.219$, respectively. On the contrary, time risk and social risk did not influence attitude of BMT management in adopting the AIS. In this way, H12, H13, and H14 are supported, while $\mathrm{H} 15$ and $\mathrm{H} 16$ are not accepted. 
Table 4. Path coefficient values

\begin{tabular}{llllll}
\hline Variables & $\mathbf{R}^{2}$ & Hypotheses & B (Beta) & t-Statistics \\
\hline Intention & $\mathbf{0 . 6 2 4}$ & H1 & Attitude & $\mathbf{0 . 4 6 5}$ & $\mathbf{2 . 9 2 2}$ \\
& & H2 & Usefulness Perception & $\mathbf{0 . 3 9 2}$ & $\mathbf{2 . 8 1 9}$ \\
Usefulness Perception & 0.754 & H6a & System Quality & $\mathbf{0 . 3 0 0}$ & $\mathbf{2 . 1 2 5}$ \\
& & H7a & Relevance & $\mathbf{0 . 1 8 8}$ & $\mathbf{1 . 9 7 7}$ \\
& & H8a & Compatibility & $\mathbf{0 . 3 1 8}$ & $\mathbf{2 . 6 2 2}$ \\
& & H9a & Screen Design & -0.033 & 0.579 \\
& & H10a & Exploring Power & -0.073 & 1.180 \\
& & H11a & Terminology & -0.058 & 1.037 \\
Ease of Use Perception & H5 & Ease of Use Perception & $\mathbf{0 . 3 6 0}$ & $\mathbf{2 . 0 5 0}$ \\
& 0.691 & H6b & System Quality & $\mathbf{0 . 2 4 0}$ & $\mathbf{2 . 1 4 1}$ \\
& & H7b & Relevance & $\mathbf{0 . 1 5 8}$ & $\mathbf{2 . 0 0 1}$ \\
& & H8b & Compatibility & -0.032 & 0.452 \\
Attitude & H9b & Screen Design & $\mathbf{0 . 3 0 5}$ & $\mathbf{2 . 8 2 5}$ \\
& & H10b & Exploring Power & $\mathbf{0 . 2 5 9}$ & $\mathbf{2 . 6 4 7}$ \\
& H11b & Terminology & $\mathbf{0 . 1 6 4}$ & $\mathbf{2 . 1 6 3}$ \\
& H3 & Usefulness Perception & $\mathbf{0 . 2 3 2}$ & $\mathbf{2 . 5 1 6}$ \\
& 0.757 & H4 & Ease of Use Perception & $\mathbf{0 . 3 2 7}$ & $\mathbf{3 . 3 2 1}$ \\
& & H12 & Performance Risk & -0.237 & 2.597 \\
& H13 & Financial Risk & -0.162 & 2.618 \\
& H14 & Security Risk & -0.219 & 3.043 \\
& H15 & Time Risk & -0.070 & 1.259 \\
& H16 & Social Risk & -0.049 & 1.014 \\
\hline
\end{tabular}

Note: Figures in bold type means that the hypothesis is supported.

\section{Discussion}

\subsection{TAM Construct}

This study used the TAM theoretical framework to explain intention of BMT management personnel toward applying AIS. The output of structural testing revealed that usefulness perception, ease of use perception, and attitude were important predictors influencing the intention of BMT management personnel to adopt AIS. Attitude of BMT management personnel directly influenced their intention to apply AIS. The positive attitude of BMT management personnel was established by their perception toward the ease of use and usefulness of AIS. They believed that AIS will be easy to apply and will be useful for the BMT, hence it could be expected that it will improve their performance. In this way, this finding confirms that TAM explains the behavior of an individual in adopting technology.

\subsection{System Characteristics}

System quality had a positive and significant influence on the ease of use perception toward the AIS. This means that the BMT management personnel expects AIS to have a good quality, be easy to navigate, be accessible any time, and present convenient features. The better the system quality is, the easier for BMT management personnel to look for information. System quality also influenced usefulness perception. This indicates that system quality is also expected to benefit the BMT management. These findings are in line with Kim et al. (2008) contending that a system that provides fast responses, reacts quickly, enhances information exchange, and accepts changes, has a positive influence on the ease of use and usefulness perception. Jeong (2011) also indicated that system quality has a positive connection with usefulness and ease of use perceptions.

Compatibility was found to be a factor with the biggest influence one usefulness perception. Compatibility refers to how far the AIS fulfilled the values and needs of BMTs. This means that the BMT management personnel wished to use a system that is compatible to BMT's requirements and can be operated in any system. The findings of this study support those of Crespo and Rodrigues (2008), who indicated that compatibility has a positive significant connection with the usefulness perception to adopt e-commerce. Compatibility was not found to have any direct influence on ease of use perception. This means that compatibility only affects the BMT's management personnel perceived usefulness of the AIS.

Relevance was also a factor influencing usefulness perception of AIS. It is reasonable to think that a system that 
is relevant to BMT's needs could generate benefits for the BMTs. Relevance also influenced the ease of use perception. This confirms the findings of Hong et al. (2002), Thong (2002), and Jeong (2011), who reported that the usefulness of technology will be obtained when someone applies a relevant tool to one's activity.

\subsection{Interface Characteristics}

Interface characteristics such as screen design, exploring power, and terminology only influenced ease of use perception. This explains how those three factors positively influenced only the BMT management's perception about ease of using AIS. This is in line with the findings of Hong et al. (2002) and Jeong (2011), who also indicated that those three factors only are associated with the ease of use perception. Among those three factors, screen design was found as the factor with the biggest influence on the ease of use perception. This implies that the BMT management wishes to apply an AIS that uses clear symbols, attractive screen layout, and interesting fonts, style, and color. Good interface design will make the system easy to use by the BMT management, positively influencing the usefulness perception. A study conducted by Thong et al. (2002) found that the interface design influenced the perceived ease of using a digital library. Hong et al. (2002) reported that a system with a good interface design will make users easy to use a digital library. Jeong (2011) also reported that the vivid and consistent screen layout with fonts, symbols, and buttons that are easy to read has positive connection with the ease of use perception.

Exploring power was also positively perceived by BMT management personnel. They assumed that a system that enables users to explore more will make them easy to search for information. Therefore, an AIS should provide a good navigation system, so that searching for information can be carried out efficiently. This is consistent Jeong (2011), who stated that a website system that allows the users to access interesting information, to easily navigate the website, or to access other websites will positively influence a system's perceived usefulness. Thong et al. (2002) also declared that a system completed with a navigation instrument will make easy to look for information.

The final factor influencing AIS ease of use is terminology, which is related to the words, sentences, and abbreviations used by the system. This means that an AIS should use terms that are easy to understand, consistent, and easy to use, so it will make easy for BMT management personnel to use the system. These findings confirm Hong et al. (2002) and Thong et al. (2002), who indicated that the choice of terminology was the strongest interface characteristic influencing ease in using a digital library. To achieve terminology clarity, an AIS may give explanation of the technical terms, so that they will be easy to understand by the users.

\subsection{Risk Perception}

Besides identifying the factors that promoted the adoption of AIS, this study also found the factors hampering the intention to adopt AIS. The findings indicate that security risk, financial risk, and performance risk affected the BMT management personnel's decision to use AIS. The negative perceptions were caused by the concern that applying AIS will cause financial loss due to input error, thus causing discrepancies in the financial reports. In addition, BMT personnel were concerned about security risks, especially regarding identity theft and hacking. The risks concerning the system leak and virus infection were also taken into account, because this issue can cause the error in the process of recording and payment during the time of transaction.

Social and time risk were not significant risk factors to adopt the AIS. This could have happened because BMT personnel believed that AIS is already an important tool to run the daily BMT transactions. Therefore, BMT managers ignored the social prejudice against the use of AIS. The risk regarding the long time required to learn to use an AIS was completely neglected by respondents. This is possibly due to the fact that BMT personnel are already used to use computers and internet.

\section{Conclusion}

This study analyzed the determinant factors that promote the adoption of AIS by BMTs. The findings confirmed the TAM theory in the context of AIS acceptance. Usefulness and ease of use perception and attitude showed positive and significant impact on the intention in using the AIS.

This study also found important determinants as the predictors of the perceptions on usefulness and ease of use of AIS. System quality and relevance were found to have positive and significant influences to the perceptions of usefulness and ease of use. Compatibility influenced usefulness perception but did not give direct influence on ease of use perception. Exploring power, screen design, and terminology only influenced the perceived ease of using AIS. This study also found that the risks associated with performance, finance, and security have negative influence on the use of AIS, while time and social risk were not influential. This can be used as a reference for the system designer of the AIS. 


\section{Recommendations}

The development of an AIS should pay attention to the system quality, relevance, and compatibility, so it can be useful and ease of use. In addition, the AIS should be able to eliminate the risks related to performance, finance, and security.

When appropriate AIS are developed according to the BMTs' needs, the software needs to be distributed to all branches. Managers need to get technical guidance so that the AIS can be applied properly.

\section{References}

Ahn, T., Ryu, S., \& Han, I. (2007). The impact of web quality and playfulness acceptance of online retailing. Information \& Management, 44(3), 263-275. http://dx.doi.org/10.1016/j.im.2006.12.008

Ajzen, I. (1991). The theory of planned behaviour. Organizational Behavior and Human Decision Processes, 50, 179-211. http://dx.doi.org/10.1016/0749-5978(91)90020-T

Bhatt, Nitin, \& Tang, S. (2002). Delivering microfinance in developing countries: Controversies and policy perspectives. Policy Studies Journal, 29,121-129.

Crespo, A. H., \& Rodrigues, I. A. (2008). Explaining B2C e-commerce acceptance: An integrative model based on the framework by Gatignon and Robertson. Interacting with Computers, 20, 212-224. http://dx.doi.org/10.1016/j.intcom. 2007.11.005

Davis, F. D. (1989). Perceived usefulness, perceived ease of use, and user acceptance of information technology. MIS Quarterly, 13(3), 319-340. http://dx.doi.org/10.2307/249008

Davis, F. D. (1993). User acceptance of information technology: System characteristics, user perceptions, and behavioral impact. International Journal Management Machine Studies, 38, 475-487. http://dx.doi.org/10.1006/imms.1993.1022

Hair, J. F., Ringle, C. M., \& Sarstedt, M. (2011). PLS-SEM: Indeed a silver bullet. Journal of Marketing Theory and Practice, 9(2), 139-151. http://dx.doi.org/10.2753/MTP1069-6679190202

Hall, J. A. (2006). Accounting Information Systems. South-Western, New Jersey.

Henseler, J., Ringle, C. M., \& Stankovic, R. R. (2009). The use of partial least squares path modeling in international marketing. Advances in International Marketing, 20, 277-319. http://dx.doi.org/10.1108/S1474-7979(2009)0000020014

Hong, W., Thong, J. Y. L., Wong, W. M., \& Tam, K. Y. (2002). Determinants of user acceptance of digital libraries: An empirical examination of individual differences and system characteristics. Journal of Management Information Systems, 18(3), 97-124.

Hu, P. J. H., Clark, T. H. K., \& Ma, W. W. (2003). Examining technology acceptance by school teachers: A $\begin{array}{lllll}\text { longitudinal study. Information } \& \text { Management, } & 41(2), & \text { 227-241. }\end{array}$ http://dx.doi.org/10.1016/S0378-7206(03)00050-8

Jeong, H. (2011). An investigation of user perceptions and behavioral intentions towards the e-library. Library Collections, Acquisitions, \& Technical Services, 35, 45-60. http://dx.doi.org/10.1016/j.lcats.2011.03.018

Karjaluato, H., T. Koivumaki, \& Salo, J. (2003). Individual Difference in Private Banking: Empirical Evidence from Finland. Proceeding of the $36^{l}$ Hawaii International Conference on System Science. Big Island, Hawaii.

Khalily, M. A. B. (2004). Quantitative approach to impact analysis of micro finance programmes in Bangladesh: What Have We Learn? Journal of International Development, 16(4), 331-353. http://dx.doi.org/10.1002/jid.1081

Khan, A. R. (2005). Poverty to profit: Using Islamic microfinance to alleviate poverty. Islamica, 15, 2-11.

Kholis, N. (2007). Evaluation to the practice of murabahah in the operations of Baitul Mai wat-Tamwil (BMT), Yogyakarta. Jurnal LaRiba, 1(1), 95-112.

Kim, T. G., Lee, J. H., \& Law, R. (2008). An empirical examination of the acceptance behaviour of hotel front office systems: An extended Technology Acceptance Model. Tourism Management, 29, 500-513. http://dx.doi.org/10.1016/j.tourman. 2007.05.016

Konchitchki, Y., \& O'Leary, D. E. (2012). Event Study Methodologies in Information Systems Research. International Journal of Accounting Information Systems, 12, 99-115. 
http://dx.doi.org/10.1016/j.accinf.2011.01.002

Lee, M. (2008). Factors influencing the adoption of internet banking: An integration of TAM and TPB with perceived risk and perceived benefit. Electronic Commerce Research and Applications, 8, 130-141. http://dx.doi.org/10.1016/j.elerap. 2008.11.006

Lee, M. (2009). Predicting and explaining the adoption of online trading: An empirical study in Taiwan. Decision Support Systems, 47,133-142. http://dx.doi.org/10.1016/j.dss.2009.02.003

Moorthy, M. K., Voon, O. O., Samsuri, C. A. S., Gopalan, M., \& Yew, K. T. (2012). Application of information technology in management accounting decision making. International Journal of Academic Research in Business and Social Sciences, 2(3), 1-16.

Pierre, A. K., Khalil, G., Marwan, K., Nivine, G., \& Tarek, A. (2013). The tendency for using Accounting Information Systems in Lebanese firms. International Journal of Computer Theory and Engineering, 5(6). http://dx.doi.org/10.7763/ IJCTE.2013.V5.818

Ritchie, B., \& Brindley, C. (2005). ICT adoption by SMEs: Implications for relationships and management. New Technology, Work and Employment, 20(3), 205-217. http://dx.doi.org/10.1111/j.1468-005X.2005.00154.x

Sadeq, A. H. M. (2007). Microfinance, Poverty alleviation and Economic Development: Theory and Practice. A Paper presented in First International Conference on Inclusive Islamic Financial Sector Development, Brunei.

Slater, D., \& Tacchi, J. (2004). Research: ICT Innovations for Poverty Reduction. UNESCO, Tokyo.

Ssewanyana, S. J. (2009). ICT Usage in Microfinance Institutions in Uganda. African Journal of Information System, 1(3), 5-28.

Surahman, D., Suhrowardi, \& Ersa, Y. (2009). Pengertian, Dasar Hukum, Sejarah dan Tujuan Berdiri. Retrieved January 22, 2013, from http://faiz2006.wordpress.com/2009/06/09/bmt-baitul-maal-wa-tamwil/

Tesic, B. (2012). Process management and success factor analysis of management information system of budget accounting of local treasuries. Management Information Systems, 7(2), 3-12.

Thong, J. Y. L., Hong, W., \& Tam, K. Y. (2002). Understanding user acceptance of digital libraries: What are the roles of interface characteristics, organizational context, and individual differences? International Journal Human-Computer Studies, 57(3), 215-242. http://dx.doi.org/10.1016/S1071-5819(02)91024-4

Ulrich, D. (1988). A new mandate for human resources. Harvard Buisiness Review, Januari-Februari, 124-134.

Venkatesh, V., \& Davis, F. D. (2000). A theoretical extension of the technology acceptance model: Four $\begin{array}{lllll}\text { longitudinal field } & \text { studies. }\end{array}$ http://dx.doi.org/10.1287/mnsc.46.2.186.11926

Venkatesh, V., Morris, M. G., Davis, G. B., \& Davis, F. D. (2003). User acceptance of information technology: Toward a unified view. MIS Quarterly, 27, 425-478.

Zakaria, W. Z. W., Rahman, S. F., \& Elsayed, M. (2011). An analysis of task performance outcomes through e-accounting in Malaysia. Journal of Public Administration and Governance, 1(2), 124-139.

\section{Copyrights}

Copyright for this article is retained by the author(s), with first publication rights granted to the journal.

This is an open-access article distributed under the terms and conditions of the Creative Commons Attribution license (http://creativecommons.org/licenses/by/3.0/). 